\title{
Autologous stem cell transplantation in autoimmune arthritis restores immune homeostasis by renewal of the natural Treg compartment
}

\author{
T van den Broek ${ }^{1 * \dagger}$, E Delemarre ${ }^{1 \dagger}$, J Meerding ${ }^{1}$, E Wehrens $^{1}$, F Broere $^{2}$, N Wulffraat $^{1}$, M Boes $^{1}$, B Prakken ${ }^{1 \dagger}$, \\ F van Wijk $^{1+}$
}

From 18th Pediatric Rheumatology European Society (PReS) Congress

Bruges, Belgium. 14-18 September 2011

Autologous stem cell transplantation (ASCT) is a last resort treatment for refractory juvenile idiopathic arthritis (JIA). It has been shown to induce dramatic and long-term improvements, but the underlying mechanisms remain to be elucidated. We investigated the potential role of regulatory $\mathrm{T}$ cells (Treg) in the processes of immune reconstitution and re-establishment of immune tolerance following ASCT.

In a mouse model of proteoglycan-induced arthritis, (pseudo)ASCT following lethal irradiation reduced arthritis scores and restored the immune balance of pro-inflammatory effector $\mathrm{T}$ cells and Treg. Directly following the ASCT the majority of Treg consisted of Treg that survived the conditioning and had expanded vigorously. After a few weeks the infused stem cell-derived Treg started dominating the Treg pool and these "new" thymus-derived Treg showed more suppressive capacity than the remaining host Treg including a more stable expression of Foxp3. A therapeutic approach was initiated by infusing extra Foxp ${ }^{\mathrm{GFP}}$ Treg together with the stem cells graft. These Treg expanded vigorously and were still present two months after the ASCT. However, by infusion of Treg the induction of stem cellderived Treg was delayed and also the restoration of immune tolerance was impaired. These data indicate that restoration of the immune balance following ASCT depends on renewal of the natural Treg pool.

\footnotetext{
* Correspondence: T.vandenbroek-2@umcutrecht.n

+ Contributed equally

'Department of Pediatric Immunology, Wilhelmina Children's Hospital,

University Medical Center Utrecht, The Netherlands

Full list of author information is available at the end of the article
}

Furthermore, infusion of Treg during ASCT seems to have a long-term negative effect on $\mathrm{T}$ cell reconstitution and re-establishment of immune tolerance.

\section{Author details}

'Department of Pediatric Immunology, Wilhelmina Children's Hospital, University Medical Center Utrecht, The Netherlands. ${ }^{2}$ Institute of Infectious Diseases and Immunology, Utrecht University, Utrecht, the Netherlands.

Published: 14 September 2011

doi:10.1186/1546-0096-9-S1-P183

Cite this article as: van den Broek et al:: Autologous stem cell transplantation in autoimmune arthritis restores immune homeostasis by renewal of the natural Treg compartment. Pediatric Rheumatology 2011 9(Suppl 1):P183.

Submit your next manuscript to BioMed Central and take full advantage of:

- Convenient online submission

- Thorough peer review

- No space constraints or color figure charges

- Immediate publication on acceptance

- Inclusion in PubMed, CAS, Scopus and Google Scholar

- Research which is freely available for redistribution 